\title{
Interactive comment on "Elucidating real-world vehicle emission factors from mobile measurements over a large metropolitan region: a focus on isocyanic acid, hydrogen cyanide, and black carbon" by Sumi N. Wren et al.
}

Sumi N. Wren et al.

sumi.wren@gmail.com

Received and published: 21 September 2018

Please see the attached PDF.

Please also note the supplement to this comment:

https://www.atmos-chem-phys-discuss.net/acp-2018-429/acp-2018-429-AC1- 
2018.

ACPD

Interactive

comment

Printer-friendly version

Discussion paper 